\title{
Status jaringan periodontal dan kebutuhan perawatan jaringan periodontal pada manula Suku Bugis dan Suku Mandar
}

\author{
Bahruddin Thalib,* Dian Angriani*** \\ *Bagian Prostodonsia \\ ** Mahasiswa Tahap Profesi \\ Fakultas Kedokteran Gigi Universitas Hasanuddin
}

\begin{abstract}
Being old is a biologic process that can not be avoided, where degeneration occurs in many ways, which finally decreases the function. These cause aging people prone to various diseases; including periodontal disease. Prevalence and severity of periodontal diseases vary in world population. These differences seem to be related with age, sex, socioeconomic, education, and also ethnic and geography. This study was aimed to investigate the periodontal tissue of aging Buginese and Mandarnese. Total samples are 390 persons (195 Buginese dan 195 Mandarnese). The condition of periodontal tissue were checked using CPITN from WHO. Of 195 samples, 88 samples of Buginese and 55 samples of Mandarnese were edentulous. The result showed periodontal disease of Buginese were bleeding $2.8 \%$, tartar $39.25 \%$, pocket of $4-5 \mathrm{~mm}$ depth, $50.47 \%$, and pocket of $6 \mathrm{~mm}$ depth, 7.48\%. Periodontal disease of Mandarnese ethnic were bleeding $2.14 \%$, tartar $53.57 \%$, pocket of $4-5 \mathrm{~mm}$ depth $21.43 \%$, and pocket of $6 \mathrm{~mm}$ depth $22.86 \%$. Therefore, the need for periodontal treatment for aging Buginese were brushing teeth instruct $100 \%$, prophylaxis $97.19 \%$, and restorative $7.46 \%$. Aging Mandarnese; were brushing teeth instruction $100 \%$, prophylaxis $97.85 \%$, and restorative $22.86 \%$.
\end{abstract}

Key words: elderly people, periodontal diseases

\begin{abstract}
ABSTRAK
Menjadi tua merupakan proses biologis yang tidak terhindarkan, karena proses degenerasi terjadi pada berbagai tingkatan yang pada akhirnya menyebabkan penurunan fungsi yang mengakibatkan manula menjadi rentan terhadap berbagai penyakit,termasuk penyakit jaringan periodontal. Prevalensi maupun derajat keparahan penyakit periodontal
\end{abstract}


beragam di berbagai negara. Perbedaan tersebut tampaknya berhubungan dengan perbedaan usia, jenis kelamin, sosioekonomi, pendidikan serta latar belakang etnik dan geografi. Penelitian ini mengukur status jaringan periodontal manula dengan latar belakang etnik Bugis dan Mandar. Jumlah sampel 390 orang (195 Suku Bugis dan 195 Suku Mandar). Status jaringan periodontal diperiksa dengan mengunakan indeks CPITN dari WHO. Dari 390 sampel terdapat 88 sampel Suku Bugis dan 55 sampel Suku Mandar tidak bergigi. Hasil penelitian menunjukkan pada Suku Bugis terjadi kerusakan

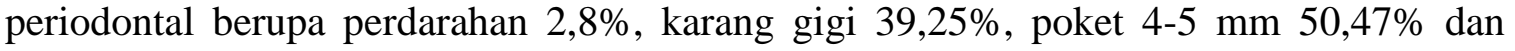
poket lebih dari $6 \mathrm{~mm} \mathrm{7,48 \%}$. Sedangkan pada Suku Mandar kerusakan periodontal

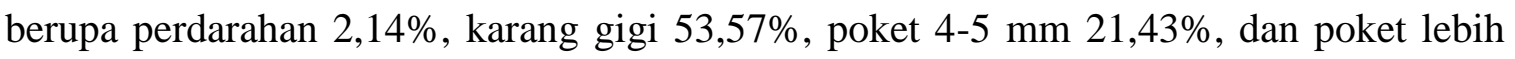

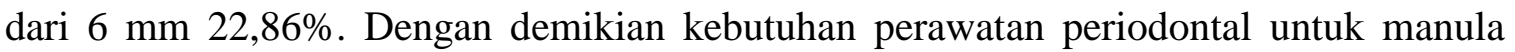
Suku Bugis adalah instruksi menyikat gigi 100\%, profilaksis 97,19\%, dan restorasi 7,47\%. Sedangkan untuk manula Suku Mandar, instruksi menyikat gigi 100\%, profilaksis $97,85 \%$, dan restorasi $22,86 \%$.

Kata kunci: manusia usia lanjut, penyakit periodontal

Koresponden: Bahruddin Thalib, Bagian Prostodonsia, Fakultas Kedokteran Gigi Universitas Hasanuddin, Jl. Kandea No.5 Makassar, Indonesia.

\section{PENDAHULUAN}

Perkembangan dalam berbagai sendi kehidupan berimplikasi pada usia harapan hidup manusia yang diproyeksikan pada tahun 2025 mencapai usia 82,1 tahun untuk perempuan dan 76 tahun untuk laki-laki untuk negara maju. Sedangkan di negara berkembang 73,8 tahun untuk perempuan dan 69,6 tahun untuk laki-laki.1 Untuk Indonesia, usia harapan hidup pada tahun 2010 diperkirakan 67 tahun untuk perempuan dan 63 tahun laki-laki. Dengan demikian jumlah populasi manula akan meningkat secara tajam. Hal tersebut membuat sangat diperlukan perhatian secara serius sehingga booming manula tidak menjadi beban tetapi malah dapat menjadi aset dalam kehidupan bermasyarakat.

Menjadi tua merupakan proses biologis yang tidak dapat dihindari, karena terjadi proses degenerasi pada berbagai tingkatan yang pada akhirnya menyebabkan penurunan fungsi dari organ-organ tubuh. Penurunan fungsi ini mengakibatkan manula 
menjadi rentan terhadap berbagai penyakit, termasuk penyakit jaringan periodontal pada rongga mulut. Masalah kesehatan gigi yang paling banyak diderita oleh manula adalah karies gigi dan penyakit periodontal, yang apabila tidak ditangani dengan baik dapat menyebabkan hilangnya gigi-geligi, yang selanjutnya mengakibatkan terganggunya fungsi kunyah, bicara dan estetik. Prevalensi penyakit periodontal khususnya pada manula tergolong cukup tinggi. Dari hasil survei nasional di Amerika pada tahun 1986, diketahui $100 \%$ manula yang berusia lebih dari 60 tahun menderita penyakit peridontal. Demikian pula di Cina, dari jumlah berjumlah 544 orang yang berusia 60-80 tahun, semuanya menderita penyakit periodontal. Sedangkan di Australia juga demikian, survey tahun 1991 kota Melbourne dan Victoria menunujukan dari 303 manula berusia 60-80 tahun, semuanya menderita penyakit periodontal.2 Di Indonesia sendiri dilaporkan prevalensi penyakit periodontal sebesar $86 \% .3$

Dari berbagai hasil penelitian epidemiologi dilaporkan bahwa baik prevalensi maupun derajat keparahan penyakit periodontal beragam antara berbagai populasi di dunia. Perbedaan tersebut tampaknya berhubungan dengan perbedaan usia, jenis kelamin, sosioekonomi, status pendidikan, serta latar belakang etnik dan geografi.4

Pada karya ilmiah ini akan dipaparkan suatu penelitian survei analitik penyakit periodontal dan kebutuhan perawatan jaringan periodontal pada manula Suku Bugis dan Suku Mandar, sehingga diketahui jenis kebutuhan perawatan jaringan periodontal yang dibutuhkan oleh kedua etnis masyarakat tersebut.

\section{BAHAN DAN METODE}

Sampel dipilih sesuai kriteria inklusi yang telah ditetapkan, yaitu berusia lebih dari 55 tahun, sehat mental dan fisik, serta tidak memiliki riwayat penyakit sistemik. Sampel Suku Bugis diperoleh di Kecamatan Mallusetasi, Kabupaten Barru, Sulawesi Selatan, sedangkan sampel Suku Mandar diperoleh di Kecamatan Pamboang, Kabupaten Majene, Sulawesi Barat. Jumlah sampel secara keseluruhan adalah 390 orang, yang terdiri dari 195 manula Suku Bugis dan 195 manula Suku Mandar. Pemeriksaan status jaringan periodontal dilakukan dengan mengunakan indeks dari WHO, yaitu community periodontal index and treatment needs (CPITN) dengan menggunakan probe sonde yang ujungnya berbentuk bola kecil berdiameter $0,5 \mathrm{~mm}$, area berwarna hitam sebagai skala berada 
pada daerah 3,5-5,5 mm. Gigi indeks yang diperiksa terdapat pada enam sekstan, yaitu insisivus pertama kiri atau kanan rahang atas dan bawah, dan molar pertama dan kedua kiri dan kanan rahang atas dan bawah. Evaluasi penilaian 0 adalah sehat, tidak terdapat perdarahan, karang gigi dan poket; 1 adalah adanya perdarahan, yang tampak secara langsung atau dengan kaca mulut setelah probing; 2 adalah adanya karang gigi, yang jika diraba dengan sonde terasa kasar; 3 adalah adanya poket kedalaman 4-5 mm sehingga hanya sebagian warna hitam pada sonde yang masih terlihat pada tepi gusi; dan 4 adalah adanya poket $6 \mathrm{~mm}$ atau lebih, dan seluruh warna hitam pada sonde tidak terlihat karena masuk ke dalam jaringan periodontal.

Dari data status jaringan periodontal ditentukan kebutuhan perawatan dengan kategori sebagai berikut, kategori 0 adalah tidak memerlukan perawatan (skor 0), kategori 1 adalah memerlukan penyuluhan peningkatan kebersihan mulut (skor 1), kategori 2 adalah memerlukan peningkatan kebersihan mulut dan skeling karang gigi (skor 2 dan 3), dan kategori 3 adalah memerlukan semua perawatan di atas ditambah kuratase dan bedah periodontal.

Data yang diperoleh akan dianalisis secara deskriptif lalu disajikan dalam bentuk tabel kemudian dianalisis berdasarkan kelompok umur, jenis kelamin, dan suku.

\section{HASIL PENELITIAN}

Berdasarkan hasil penelitian yang dilakukan pada manula Suku Bugis yang berada di Kecamatan Mallusetasi Kabupaten Barru dan Suku Mandar di Kecamatan Pamboang Kabupaten Majene dapat diketahui tingkat keparahan penyakit periodontal, luasnya masalah serta kebutuhan perawatan penyakit periodontal pada manula Suku Bugis dan Suku Mandar. Dari 195 sampel terdapat 88 orang (45\%) sampel tidak bergigi untuk Suku Bugis, sehingga tersisa 107 sampel yang diperiksa jaringan periodontalnya. Pada sampel Suku Mandar, dari 195 sampel terdapat 55 (28\%) sampel yang tidak bergigi, sehingga hanya 140 orang yang diperiksa jaringan periodontalnya. 
Tabel 1. Tingkat keparahan penyakit periodontal pada manula suku bugis dan suku mandar

\begin{tabular}{|c|c|c|c|c|c|c|}
\hline \multirow{2}{*}{ Suku } & \multirow{2}{*}{$\mathrm{N}$} & \multicolumn{5}{|c|}{ Evaluasi Penilaian } \\
\hline & & $\begin{array}{c}0 \\
\text { (Sehat) } \\
\end{array}$ & $\begin{array}{c}1 \\
(\text { Berdarah }) \\
\end{array}$ & $\begin{array}{c}2 \\
\text { (Karang Gigi) }\end{array}$ & $\begin{array}{c}3 \\
(\text { Poket4-5 mm) } \\
\end{array}$ & $\begin{array}{c}4 \\
(\mathrm{POKET} \geq 6 \mathrm{MM})\end{array}$ \\
\hline \multirow{2}{*}{ Bugis 107} & & 0 & 3 & 42 & 54 & 8 \\
\hline & & $0 \%$ & $2,80 \%$ & $39,25 \%$ & $50,47 \%$ & $7,48 \%$ \\
\hline \multirow{2}{*}{ Mandar 140} & & 0 & 3 & 75 & 30 & 32 \\
\hline & & $0 \%$ & $2,14 \%$ & $53,57 \%$ & $21,43 \%$ & $22,86 \%$ \\
\hline
\end{tabular}

Keterangan : $\mathrm{N}$ : besar sampel

Pada tabel 1 terlihat bahwa persentase terbesar penyakit periodontal manula Suku Bugis adalah poket periodontal 4-5 mm $(50,47 \%)$ kemudian adanya karang gigi sebesar $39,25 \%$, poket lebih dari $6 \mathrm{~mm}$ $7,48 \%$, dan perdarahan $2,80 \%$. Tidak ada satupun sampel yang sehat jaringan periodontalnya baik pada Suku Bugis maupun Suku Mandar. Selanjutnya terlihat bahwa untuk suku Mandar persentase terbesar kerusakan jaringan periodontal adalah karang gigi yaitu 53,57\%, disusul poket $\geq 6$ sebanyak $22,86 \%$, poket $5 \mathrm{~mm}$ sebanyak $21,43 \%$, dan perdarahan sebanyak $2,14 \%$. 
Tabel 2. Tingkat keparahan penyakit periodontal dari skor CPITN tertinggi berdasarkan jenis kelamin pada manula Suku Bugis dan Suku Mandar

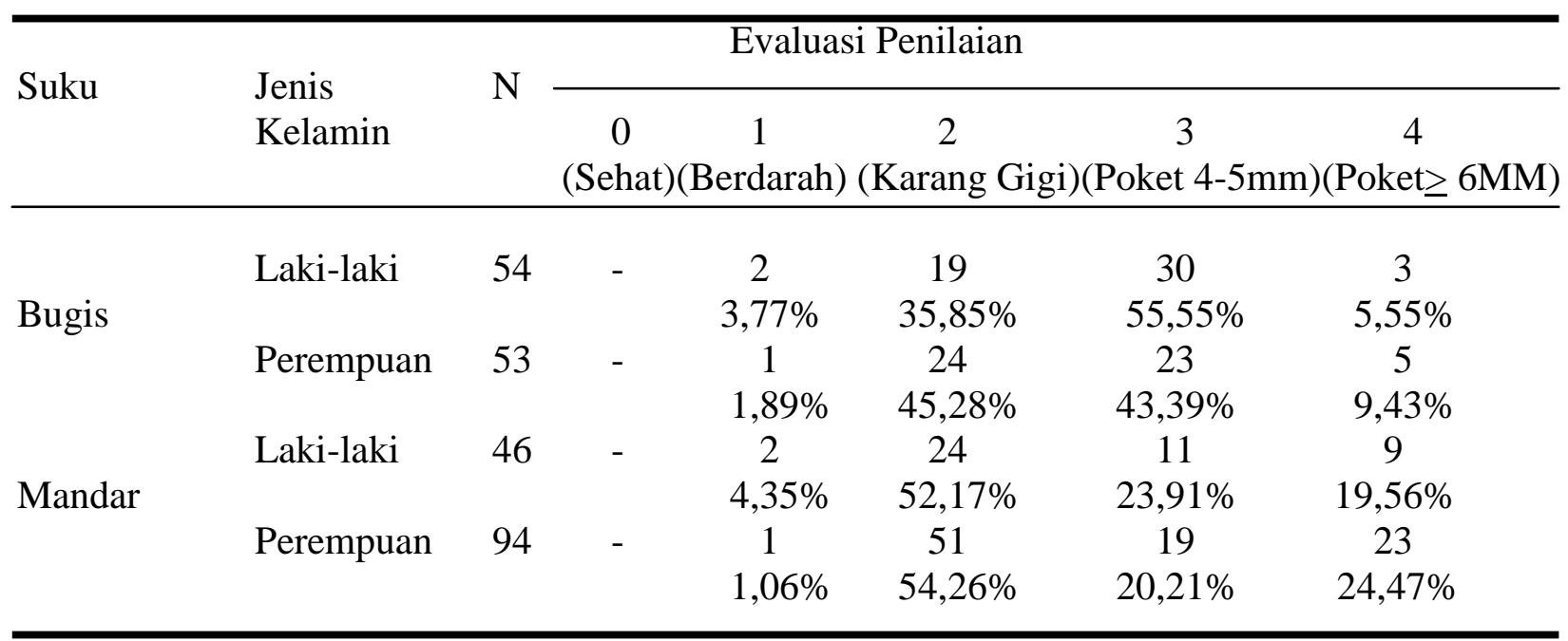

Keterangan : $\mathrm{N}$ : besar sampel

Dari tabel 2 ditunjukkan bahwa sebagian besar manula laki-laki Suku Bugis menderita poket periodontal $4-5 \mathrm{~mm}$, yaitu sebanyak 55,55\%. Jumlah ini lebih besar dari manula perempuan sebanyak 43,39\% . Sedangkan untuk manula perempuan persentase pengidap karang gigi lebih tinggi $(45,28 \%)$ daripada manula laki-laki $(35,85 \%)$. Untuk penderita poket periodontal $\geq 6 \mathrm{~mm}$, jumlah manula perempuan hampir dua kali manula laki-laki (bandingkan 9,43\% dengan 5,55\%).

Sedangkan laki-laki Suku Mandar $52,17 \%$ menderita karang gigi. Perempuan Suku Mandar juga kebanyakan mengalami karang gigi, yakni 54,26\%. Sedangkan untuk poket periodontal $\geq 6 \mathrm{~mm}$, perempuan Suku Mandar juga lebih banyak dari pada laki-laki meski tidak semenyolok Suku Bugis.

Berdasarkan kelompok umur, pada manula Suku Bugis terlihat bahwa kelompok umur 55-65 tahun dan 66-75 sebagian besar menderita poket periodontal (berturut-turut 52,94\% dan 53,85\%). Setelah itu baru kemudian adanya karang gigi karang gigi (berturut-turut 35,29\% dan $38.46 \%$ ), seperti yang terlihat pada tabel 3 . Sedangkan secara keseluruhan manula Suku Bugis 50,47\% mengalami poket 4-5 mm dan $39,25 \%$ mengalami karang gigi. 
Tabel 3. Tingkat keparahan penyakit periodontal berdasarkan kelompok umur lansia Suku Bugis

\begin{tabular}{|c|c|c|c|c|c|c|}
\hline \multirow{2}{*}{$\begin{array}{l}\text { Kelompok } \\
\text { Umur }\end{array}$} & \multicolumn{5}{|c|}{ Evaluasi Penilaian } & \multirow{2}{*}{$\begin{array}{l}\text { Jumlah } \\
\text { (orang) }\end{array}$} \\
\hline & $\begin{array}{c}0 \\
\text { (Sehat) }\end{array}$ & $\begin{array}{c}1 \\
\text { (Berdarah) }\end{array}$ & $\begin{array}{l}2 \\
\text { (Karang Gigi) }\end{array}$ & $\begin{array}{c}3 \\
\text { (Poket4 }\end{array}$ & $\begin{array}{l}\quad 4 \\
\text { (POKET } \geq 6 \mathrm{MM})\end{array}$ & \\
\hline & 0 & 3 & 30 & 45 & 7 & 85 \\
\hline $55-65$ & & $3,52 \%$ & $35,29 \%$ & $52,94 \%$ & $8,25 \%$ & \\
\hline & 0 & 0 & 5 & 7 & 1 & 13 \\
\hline $66-75$ & & & $38,46 \%$ & $53,85 \%$ & $7,69 \%$ & \\
\hline & 0 & 0 & 6 & 2 & 0 & 8 \\
\hline $76-85$ & & & $75,0 \%$ & $25,0 \%$ & & \\
\hline $86-95$ & 0 & 0 & $\begin{array}{c}1 \\
100 \%\end{array}$ & 0 & 0 & 1 \\
\hline Jumlah & 0 & $\begin{array}{c}3 \\
2,80 \%\end{array}$ & $\begin{array}{c}42 \\
39,25 \%\end{array}$ & $\begin{array}{c}54 \\
50,47 \%\end{array}$ & $\begin{array}{c}8 \\
7,48 \%\end{array}$ & 107 \\
\hline
\end{tabular}

Tabel 4. Tingkat keparahan penyakit periodontal pada manula Suku Mandar berdasarkan kelompokumur

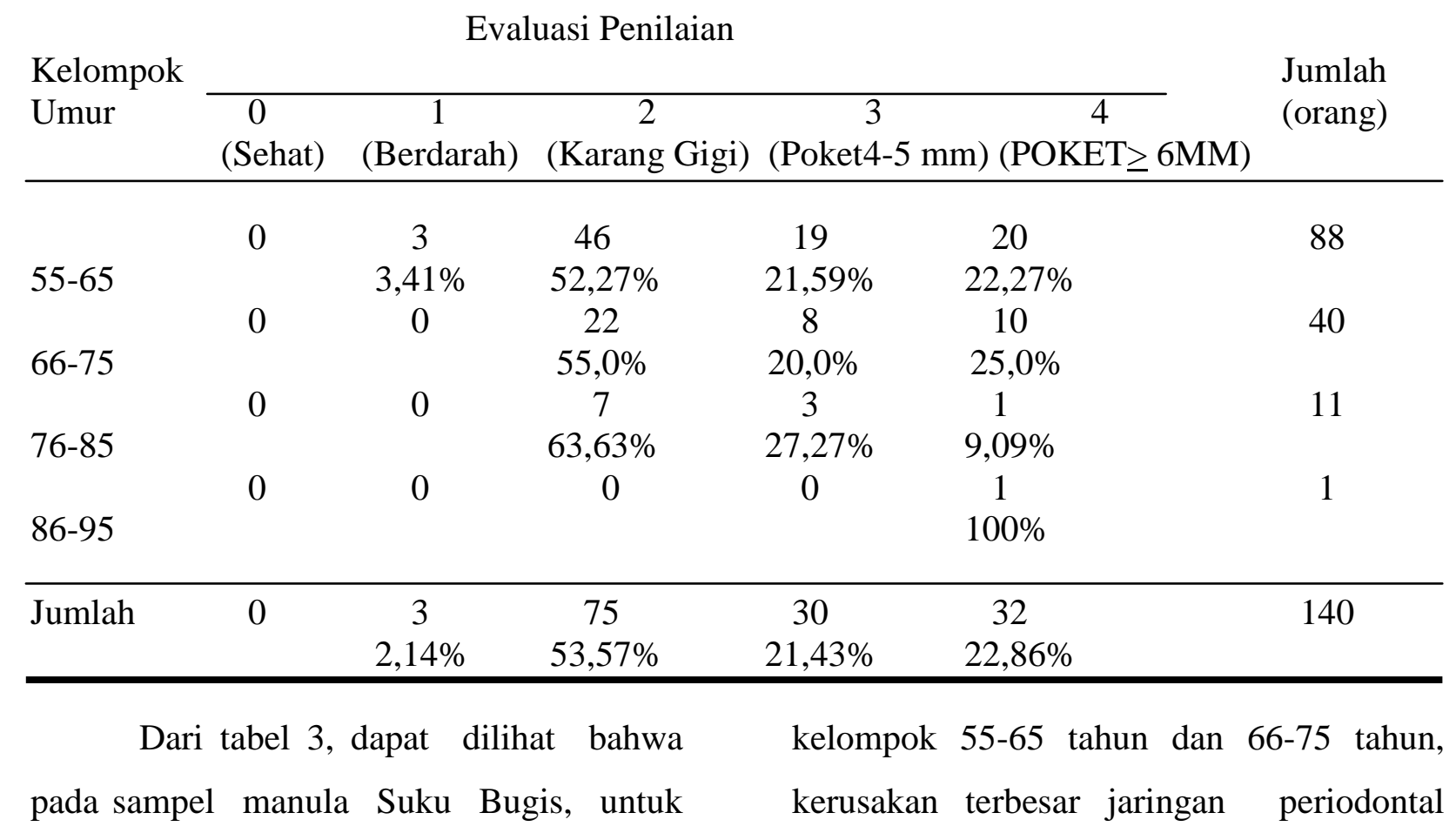


terjadi karena adanya poket $4-5 \mathrm{~mm}$ (berturut-turut $52,94 \%$ dan 53,85\%), kemudian usia di atasnya mayoritas menderita karang gigi. Sedangkan pada sampel Suku Mandar, untuk kelompok 5565 tahun, 66-75 tahun, dan 76-85 tahun kerusakan terbesar jaringan periodontal terjadi karena adanya karang gigi (berturutturut 52,27\%, 55,0\%, dan 63,63\%).

\section{PEMBAHASAN}

Penelitian ini dilaksanakan di Kabupaten Barru untuk Suku Bugis, dan Kabupaten Majene untuk Suku Mandar dengan alasan homogenitas sampel. Kedua daerah tersebut memiliki populasi yang relatif masih homogen secara ekonomi, sosial dan budaya. Selain itu dengan asumsi bahwa pola hidup dan pola makan masih sama pada masing- masing suku. Batas usia manula yang digunakan sebagai sampel adalah 55 tahun ke atas sesuai dengan usia pensiun dan ketetapan Direktorat Pelayanan Kesehatan Depkes. Respoden secara keseluruhan diperoleh 390 orang, yaitu 195 orang untuk Suku Bugis dan 195 orang untuk Suku Mandar. Berdasarkan jenis kelamin manula, perempuan jumlahnya lebih besar (65\%) daripada manula laki-laki (35\%). Data penelitian ini memperlihatkan perbandingan jumlah perempuan dengan laki-laki adalah 1,8:1. Hal ini sesuai dengan hasil sensus penduduk yang menunjukan jumlah perempuan lebih banyak dari lakilaki.

Berdasarkan kelompok usia, kelompok 55- 65 tahun mempunyai jumlah yang terbanyak dengan persentase 66,25 $\%$. Hal ini sesuai dengan usia harapan hidup masyarakat Indonesia sekarang yaitu 63 tahun. 4

Prevalensi kerusakan jaringan periodontal meningkat sejalan dengan peningkatan usia. Berbagai perubahan pada jaringan periodontal manula mengakibatkan lemahnya daya tahan jaringan periodontal terhadap berbagai iritasi, utamanya plak bakteri. Akumulasi pembentukan plak pada manula lebih cepat terjadi dibandingkan dengan usia muda karena adanya perubahan fisiologis dari saliva atau terbukanya jaringan sementum yang permukaannya kasar sehingga memudahkan terjadinya pembentukan plak gigi. Diet lunak yang dikunsumsi oleh manula, berkurangnya aktivitas mulut dan peningkatan insiden serostomia juga berperan pada pembentukan plak gigi. Plak gigi diyakini sebagai penyebab utama terjadinya kerusakan jaringan periodontal. Pada penelitian ini dapat dikatakan bahwa semua sampel 
(100\%) menderita penyakit periodontal pada berbagai tingkatan, oleh karena tidak satupun sampel dikategorikan sehat. Hasil ini lebih tinggi dari yang dilaporkan oleh Departemen Kesehatan RI,3 yang hanya 86 $\%$.

Lebih besarnya persentase poket periodontal pada manula Suku Bugis dibandingkan manula Suku mandar juga seiring dengan lebih besarnya jumlah kehilangan gigi total pada manula Suku Bugis daripada manula Suku Mandar. Poket Periodontal yang tidak dirawat akan berlanjut pada kehilangan tulang alveolar yang dapat menyebabkan goyangnya gigigeligi dan pada akhirnya mengakibatkan tanggalnya gigi tersebut.5 Lebih besarnya kerusakan jaringan periodontal pada manula Suku Bugis mungkin disebabkan oleh faktor aktivitas merokok; oleh karena pada penelitian ini juga diperoleh data jumlah manula perokok dua kali lebih besar pada manula Suku Bugis dibandingkan manula Suku Mandar. Dilaporkan pula bahwa pada perokok terjadi kerusakan fungsi mikrosirkulasi gingival sehingga mengganggu suplai oksigen dan nutrisi, menghalangi sistem imun host terhadap infeksi, dan juga berpengaruh buruk terhadap fungsi netrofil.6 Hal lain yang mungkin menyebabkan tingginya persentase poket periodontal pada manula Suku Bugis adalah jenis jajanan tradisional Suku Bugis umumnya "manis-manis" dengan konsistensi yang lunak.7 Makanan yang lunak lebih mudah melekat pada permukaan gigi, sehingga akumulasi bakteri plak capat terbentuk.

\section{SIMPULAN}

Penyakit periodontal ditemukan secara menyeluruh pada sampel yang dengan tingkat keparahan pada Suku Bugis yaitu poket periodontal 58\%, karang gigi $39 \%$ dan perdarahan probing $3 \%$. Sedangkan pada manula Suku Mandar karang gigi $54 \%$, poket periodontal $44 \%$ dan perdarahan probing $2 \%$.

Kebutuhan perawatan jaringan periodontal untuk manula Suku Bugis adalah $100 \%$ intruksi menyikat gigi, 97,19\% memerlukan tindakan profilaksis dan 7,47\% membutuhkan tindakan restoratif. Untuk manula Suku Mandar, instruksi menyikat gigi $100 \%$, tindakan profilaksis $97,85 \%$ dan tindakan restoratif $22,86 \%$.

\section{Ucapan terima kasih}

Penelitian ini didanai oleh Hibah Penelitian PHK A2 FKG Unhas 2005 


\section{DAFTAR PUSTAKA}

1. Matthiessen PC. Demography-impact of an expanding elderly population. In: Pedderson PH, Loe $\mathrm{H}$, editors. Textbook of geriatric dentistry, 2nd ed. Munksgaard; 1996. p.505-16.

2. WHO. Oral health country profile program; 2000.

3. Departemen Kesehatan Republik Indonesia, 1994. Pedoman pembinaan kesehatan usia lanjut, Jakarta: Depkes; 1994. p. 5-18.

4. Prayitno SW. Karakteristik penyakit periodontal lanjut pada suatu studi epidemiologi. Kumpulan Makalah Ilmiah Kongres PDGI XVIII. 1992: 308-15.

5. Barnes I. Walls A. Gerodontology. Oxford: Wright; 1994. p.17-27.

6. Beck JD, Loe H. Relationship between smoking duration and alveolar bone loss. J Periodontol 2001; 71:1375-84.

7. Pelras C. Manusia Bugis. Alih bahasa Abu AR, Hasriadi, Sirimorok N. Jakarta: Nalar; 2006. p.3-19 